Đurđana Ozretić Došen * Ana Buljat ${ }^{* *}$
JEL klasifikacija: M31, M37, Z12, Z33

Izvorni znanstveni rad

https://doi.org/10.32910/ep.72.2.4

\title{
MARKETING USLUGA DOMINIKANSKIH MUZEJA U REPUBLICI HRVATSKOJ
}

Vjerske organizacije $i$ zajednice posjeduju te u svojim muzejskim ili galerijskim prostorima čuvaju jedinstvenu kulturno-umjetničku baštinu. Unatoč znatnom opsegu i iznimnoj vrijednosti zbirki, dostupnost i prezentacija građe javnostima još uvijek su skromne. Ovaj je rad posvećen marketingu usluga muzeja dominikanskih samostana kao posebnog oblika neprofitnih vjerskih organizacija. Svrha rada je istražiti koriste li dominikanski muzeji, kako i u kojem opsegu marketing u osmišljavanju i pružanju svojih usluga. Provedeno je izviđajno kvalitativno istraživanje. Rezultati ukazuju na prisutnost ograničenog broja marketinških aktivnosti koje se provode u cilju prezentiranja muzejske građe zainteresiranim korisnicima. Uočena je potreba intenziviranja marketinškoga pristupa, prije svega u praćenju trendova $u$ potrebama $i$ željama konzumenata muzejskih usluga kulture $i$ umjetnosti te u komunikaciji sa zainteresiranim korisnicima i javnostima. Za unapređenje marketinških aktivnosti važna je edukacija i zapošljavanje osoba koje brinu o muzejskoj građi, $i$ to ne samo u smislu očuvanja baštine nego i marketinškom, a kako bi se uslugu muzeja dominikanskih samostana oblikovalo kao posebni, informativni i obrazovni doživljaj/iskustvo. Ograničenja istraživanja vezana su uz prirodu kvalitativnog istraživanja i činjenicu da ona počivaju na specifičnim podacima, a vjerodostojnost tumačenja podataka je

* Đ. Ozretić Došen, dr.sc., redovita profesorica u trajnom zvanju, Sveučilište u Zagrebu, Ekonomski fakultet (e-mail: dozretic@efzg.hr).

** A. Buljat, mag. paed. relig. et catech., Hrvatska dominikanska provincija Navještenja B. D. Marije,Zagreb (e-mail: ana.buljat25@gmail.com). Rad je primljen u uredništvo 24.07.2019. godine, a prihvaćen je za objavu 27.02.2020. godine. 
Đ. OZRETIĆ DOŠEN, A. BULJAT: Marketing usluga dominikanskih muzeja u Republici Hrvatskoj EKONOMSKI PREGLED, 72 (2) 224-248 (2021)

ovisna o njihovoj točnosti i potpunosti. Doprinos rada proizlazi prije svega iz odabira originalnog istraživačkog problema i dobivenih rezultata kojima se obogaćuje teorija i znanstvena bibliografija iz područja neprofitnog (vjerskog) marketinga i marketinga usluga (u kulturi i umjetnosti).

Ključne riječi: marketing usluga muzeja, marketing vjerskih organizacija i zajednica, muzeji dominikanskih samostana u Republici Hrvatskoj

\section{UVOD}

Vjerske organizacije i zajednice imaju sve veću ulogu u suvremenom društvu s obzirom na prirodne čovjekove potrebe za duhovnošću, preispitivanjem smisla vlastitoga života, pripadnošću i slično. Isto tako, vjerske organizacije i zajednice nerijetko su vlasnici i čuvari jedinstvenih, iznimno vrijednih zbirki kulturnoumjetničke baštine te pružaju usluge upoznavanja, razgledavanja i u određenom opsegu korištenja specifičnih dijelova građe zainteresiranim korisnicima, a u okviru muzeja ili galerije vjerske organizacije ili zajednice. Imajući na umu brojnost, raznovrsnost i složenost usluga vjerskih organizacija i zajednica postavlja se pitanje u kojoj mjeri one, nudeći usluge ciljnim korisnicima, prepoznaju prilike koje im marketing pruža za osmišljavanje i/ili poboljšanje usluga, posebice onih muzejskih u području kulture i umjetnosti.

U radu se razmatra marketing usluga muzeja dominikanskih samostana kao posebnog oblika neprofitnih, vjerskih organizacija. Samostani Hrvatske dominikanske provincije udomljuju brojna djela slikarstva i kiparstva, jedinstvenu knjižničnu građu, relikvije, misna ruha i druge vrijedne predmete koji svjedoče o višestoljetnoj predanosti dominikanaca prikupljanju, brizi i očuvanju hrvatske kulturno-umjetničke baštine. Vrata samostanskih muzejskih zbirki dominikanci su javnostima otvorili još u 16. stoljeću. No u kojoj mjeri danas koriste marketing u svojem djelovanju i uvažavaju li promjene u ponašanju i potrebama svojih ciljnih skupina?

Prethodnih marketinških istraživanja u kontekstu kulturno-umjetničke baštine u vlasništvu vjerskih organizacija i zajednica u znanstvenoj literaturi u područjima neprofitnog (vjerskog) i marketinga usluga (u kulturi i umjetnosti), prema saznanjima autorica, nema. Prije više od desetljeća Timothy i Boyd (2006), ukazali su na potrebu pomnijeg istraživanja jedinstvenih izazova i pristupa upravljanju različitim oblicima baštine, posebice u kontekstu njezinih mogućnosti za generiranje turizma. Ovaj rad je posvećen razmatranjima primjene i korištenja marketinga u

muzejima dominikanskih samostana, a svrha mu je, temeljem provedenog izviđajnog, kvalitativnog istraživanja, ispuniti dva specifična cilja: 
- omogućiti bolje razumijevanje načina i praksi oblikovanja usluga muzeja dominikanskih samostana;

- dobivanje uvida u kojoj mjeri dominikanski samostani primjenjuju marketing u aktivnostima koje se tiču kulture i umjetnosti.

Rad je podijeljen u pet dijelova. Nakon uvoda, u dijelu posvećenom teorijskom okviru sažeto se navode karakteristike marketinga vjerskih organizacija i razmatraju specifičnosti muzeja u njihovom vlasništvu. Treći dio rada usredotočen je na istraživački kontekst dominikanskih muzeja u Republici Hrvatskoj kroz prezentaciju dominikanskih samostana i kulturno-umjetničke baštine u njihovim muzejskim zbirkama. Slijede opis provedenog izviđajnog istraživanja s nalazima i interpretacijom te zaključna razmatranja.

\section{TEORIJSKI OKVIR}

\subsection{Marketing vjerskih organizacija}

Neprofitne organizacije koriste marketing u sve većoj mjeri, „uzimajući“ iz marketinga profitnoga sektora one pristupe i elemente koji su prikladni za primjenu i u neprofitnom djelovanju. No što je s marketingom vjerskih organizacija? Prema Abreu (2006), marketing kao univerzalni sustav za sve vrste i oblike organizacija koje žele uspješno ostvariti svoju misiju, povećati zadovoljstvo korisnika i bolje odgovoriti na promjene u okruženju, predstavlja vrijedan, legitiman, prikladan i koristan pristup za upravljanje vjerskom organizacijom koja se aktivno bavi vlastitim poboljšanjem i shvaća svoju dužnost uključivanja u stvaranje boljeg društva. U tom smislu, marketing ne smije biti zamjena za misiju organizacije i narušavati temeljni koncept duhovnosti, već se njegovom primjenom analiziraju, planiraju, implementiraju i kontroliraju procesi u svrhu boljih odnosa vjerske organizacije s ciljnim skupinama i zadovoljavanja njihovih duhovnih i društvenih potreba. Ukazujući na promjene u marketingu vjerskih organizacija u američkom okruženju tijekom dvaju desetljeća, Einstein $(2008,2011)$ naglašava povećanje raspona korištenja te uvođenje sofisticiranih marketinških pristupa u istraživanju potreba vjernika i oblikovanju asortimana usluga, a upravljanje markom smatra sljedećim korakom u razvoju marketinga vjerskih organizacija. Ipak, McGraw, Schwartz i Tetlok (2012) upozoravaju na potrebu promišljene i adaptirane primjene marketinga u vjerskim organizacijama budući da i najmanje pretjerivanje u korištenju komercijalnih strategija može izazvati odbojnost vjernika, njihovo nezadovoljstvo, čak i napuštanje vjerske organizacije. 
Postoje mnoge predrasude o marketingu vjerskih organizacija zbog nerazumijevanja koncepta marketinga i mišljenja da su njegovi alati nespojivi s duhovnošću. Pavičić navodi (2001, str. 118): Na primjeru nekih domaćih vjerskih zajednica (Pavičić, 2000) pokazalo se da uspjeh u provođenju konkretnih marketinških aktivnosti nije bezuvjetno vezan uz pozitivnu i pravilnu percepciju marketinga kao kompleksne društvene filozofije, već je vezan uz pozitivnu percepciju aktivnosti, koje se kontekstualno i ad hoc mogu smatrati marketinškima, ali se u konkretnoj neprofitnoj organizaciji, kao takve ne doživljavaju/nazivaju.

Prema Meleru (2003), marketing vjerskoj organizaciji omogućuje razmjenu vrijednosti, pri čemu je cilj olakšati i ubrzati tijek vrijednosti prema korisnicima, tj. populaciji kojoj vjerska zajednica služi (u smislu zadovoljavanja njihovih duhovnih, društvenih i drugih osobnih potreba), uz istodobno olakšavanje i ubrzavanje tijeka vrijednosti vjerske zajednice (u smislu društvenog i kongregacijskog prihvaćanja crkvenog učenja, participacije u obavljanju funkcija vjerske zajednice, novčanim prilozima i sl.), na obostranu korist. Marketinški proces vjerskih organizacija trebao bi se oslanjati na misiju organizacije, točno određivanje ciljne(ih) skupine(a) korisnika, analizu konkurenata, ispravno odlučivanje o glavnim strateškim pravcima djelovanja, razvoj ponude proizvoda i usluga te osmišljavanje i implementaciju relevantnih komunikacijskih alata (Abreu, 2006).

\subsection{Uloga marketinga u muzejima}

Važnost marketinga za održivost muzeja prepoznata je 1980-ih (Komarac 2013, prema Rentschler, 2002). Tijekom vremena, fokus marketinga u muzejima se kretao i mijenjao od usredotočenosti na predmete (muzejsku građu), komunikaciju prema korisnicima (uključivo napore za izgradnju marke muzeja) do diferencijacije usluga muzeja i prihvaćanja marketinške orijentacije kao filozofije poslovanja (Rentschler, 2004). U skladu s rastućim značenjem paradigmi ekonomije doživljaja (Pine i Gilmore, 1998) muzeji su primorani, na sve konkurentnijem tržištu, usredotočiti se na upravljanje holističkih doživljaja i iskustava svojih posjetitelja (Rentschler i Gilmore, 2002). Mencarelly i Pulh (2012) posebno ukazuju na važnost konstrukta inteligentne zabave, sa svrhom ponude posjetiteljima privlačnih doživljaja. Potrebno je razvijati učinkovite marketinške strategije koje će osim konkurentnosti omogućiti povećanje lojalnosti, a u okviru kojih kontinuirano mjerenje i poboljšanje kvalitete usluge zauzima vrlo važno mjesto (Maher, Clark, i Gambill Motley, 2011). Štoviše, Forgas-Coll, Palau-Saumell, Matute i Tarrega (2017) su ustanovili kako su doživljaj posjeta muzeju, razina uključenosti posjetitelja i kvaliteta pružene usluge ključni poticaji zadovoljstva posjetitelja. 
Tehnološke inovacije i mogućnosti uvelike djeluju na muzejsko poslovanje, pa se pojava i razvoj virtualnih muzeja prepoznaju kao važan trend, između ostaloga i u približavanju kulture onim ciljnim javnostima koje nisu u mogućnosti fizički posjetiti muzeje (Komarac, Ozretic-Dosen, Skare, 2014). Ipak, muzejski stručnjaci su još uvijek suzdržani u prihvaćanju marketinga, iako su, kako navodi Cole (2008), povećanje broja posjetitelja i orijentacija na posjetitelje (korisnike usluga) važni argumenti u korist smanjivanja financijske ovisnosti muzeja od izvora javnog novca. Za upravitelje i marketinške menadžere upravo je određivanje cijene ulaznica za posjet muzeju posebno problematično, odnosno kako ističu Rentschler, Hede i White (2007) nerijetko predstavlja glavni problem marketinškog planiranja, budući da su muzeji navikli dobivati sredstva od javnih tijela (resornih ministarstava) te fondacija i zaklada, a sada je tim izvorima nedostatnih sredstava neophodno priključiti prihode od posjetitelja (od ulaznica i prodaje predmeta iz asortimana muzejskih prodavaonica).

Primjena marketinga u muzeju iziskuje vrlo detaljno uvažavanje specifičnosti vrste, veličine i postava muzeja, raspoloživih resursa (ljudskih, materijalnih) itd. Primjeri uspješnog marketinga u muzejima, u globalno poznatima poput američkih Smithsoniana i Metropolitan Museum of Art, europskima kao što su primjerice Louvre i Prado, ili hrvatskima Muzeju suvremene umjetnosti u Zagrebu te Muzeju vučedolske kulture u Vukovaru mogu biti dobar putokaz i poticaj marketinškim stručnjacima u pronalaženju pristupa koji ce najbolje odgovarati pojedinom muzeju. Kao posebno zanimljiv i vrijedan ogledni primjer za muzeje vjerskih organizacija i zajednica koji žele prezentirati kulturno-umjetničku baštinu mogu biti Musei Vaticani, čiji pristup vrlo uspješno harmonizira marketing neprofitnih vjerskih organizacija s marketingom u kulturi i umjetnosti.

\subsection{Specifičnosti marketinga usluga muzeja vjerskih organizacija}

Primijene li se načela marketinškog procesa za vjerske organizacije na područja primjene marketinga u njihovim institucijama kulture i umjetnosti, važno je, prije svega, utvrditi misiju i ciljeve kulturne institucije (muzeja, galerije) unutar vjerske organizacije te prepoznati i odrediti ciljne grupe korisnika kojima je usluga namijenjena. McKercher i du Cros (2002) navode kako posebnu pozornost zaslužuju odluke o tome kako najbolje i najučinkovitije predstaviti specifičnu kulturnoumjetničku baštinu različitim ciljnim korisnicima. Očekivanja suvremenih korisnika muzejskih usluga oblikovana su novim trendovima konvergencije obrazovanja i zabave, često uz pomoć primjene novih tehnologija (Komarac, Ozretic-Dosen i Skare, 2019). Budući da je svrha neprofitnih organizacija kulture i umjetnosti 
očuvanje i zaštita kulturnih dobara te njihova prezentacija javnostima, marketing bi trebao biti usmjeren ciljnoj skupini korisnika na način da najbolje odražava ono što organizacija jest i želi biti. Upravo zato je važno osvijestiti kakvu „sliku o sebi““ organizacija (muzej dominikanskog samostana) želi stvoriti u svijesti korisnika te marketinške napore kreiranja i pružanja usluga k tome usmjeriti.

Iako latinskog podrijetla, riječ muzej izvorno je izvedenica iz grčkog pojma mouseion koji označava „svetište Muza“, a ono prema klasičnoj grčkoj mitologiji pripada božicama (njih devet) umjetnosti i znanosti (https://mymodernmet.com/history-of-museums/). Prema tome, muzeji kao mjesta posvećena razmišljanju i učenju postoje neprekidno još od vremena antičke Grčke. I stoljećima kasnije njihova je uloga vezana uz obrazovanje, odnosno kako navodi McLean (2002, str. 12): $U$ devetnaestom stoljeću obrazovanje je bila misija koja je imala vjerski žar. Poveže li se učenje svećenika-redovnika s razmatranjem, odnosno kontemplacijom, muzeji vjerskih organizacija su upravo takva mjesta, a njihov je cilj usmjeren učenju, naviještanju Radosne vijesti i duhovnoj skrbi. Stoga nije čudno da su i dominikanci - „Red intelektualaca“ koji je od samoga početka djelovanja poznat kao red koji je mnogo važnosti pridavao obrazovanju i učenju te osnivao škole i sveučilišta po cijelome svijetu - u svojim građevinama prenosili znanje i obrazovali sve one koji su se oko njih okupljali.

Ako se u obzir uzmu značajna uloga koju kultura i umjetnost općenito imaju na razvoj društva te misija muzeja da pridonose općoj dobrobiti društva (u ekonomskom smislu, kao dio turističke ponude i slično), muzeji onda zasigurno imaju pred sobom zadaću razvijati se u skladu sa zahtjevima vremena kako bi mogli ispuniti postavljene društvene (dugoročne) ciljeve unutar svoje djelatnosti (Pavičić, Alfirević, i Aleksić, 2006). Iskustvo i doživljaji korisnika usluga kulture i umjetnosti, u ovom slučaju muzeja, trebaju predstavljati prioritetni fokus menadžera kulturnih organizacija. Odnosno, kako navode Buljubašić, Borić i Hartman Tolić (2016) muzeji moraju prilagoditi svoje aktivnosti potražnji na tržištu, kombiniranjem kreativnog marketinga s promjenama u okruženju. Upravo će upravljanje marketingom u muzejima omogućiti njihovu uspješniju integraciju u suvremeno okruženje poslovanja institucija u kulturi i umjetnosti, čiji korisnici imaju rastuća očekivanja po pitanju jedinstvenih doživljaja obrazovno-zabavnih sadržaja (Komarac, Ozretic-Dosen i Skare, 2017).

Zakon o muzejima (2018, čl. 3. (2)) muzej definira kao pravnu osobu ili ustrojstvenu jedinicu pravne osobe (muzej u sastavu) koja obavlja muzejsku djelatnost u svrhu proučavanja, obrazovanja i uživanja u materijalnoj i nematerijalnoj baštini čovječanstva i njegova okoliša, u službi društva i njegova kulturnoga $i$ gospodarskoga razvitka, otvorena za javnost. Muzeji mogu biti javni i privatni, pri čemu je osnivač javnih muzeja Republika Hrvatska i jedinice lokalne i područne (regionalne) samouprave ili pravna osoba u njihovu pretežitom vlasništvu, dok su 
osnivači privatnih muzeja druge pravne ili fizičke osobe (Zakon o muzejima, čl. 3. (3-4)). Muzeji vjerskih zajednica u hrvatskom zakonodavstvu (Zakon o muzejima, čl. 3. (5)) definirani su kao: stalne izložbe muzejske građe vjerske zajednice dostupne javnosti.

Prema uredbama koje je još 1973. godine Biskupska konferencija Jugoslavije (BKJ) donijela, pravne osobe Katoličke Crkve mogu osnivati: crkvene arhive, crkvene knjižnice, crkvene muzeje i crkvene muzejske zbirke. Uredba Hrvatske biskupske konferencije (HBK) iz 2000. godine (http://hbk.hr/dokumenti-hbk/uredba-hbk-o-crkvenim-muzejima-i-muzejskim-zbirkama/ i Hrvatska biskupska konferencija, 2001, 9-10) crkveni muzej definira kao muzej koji je na razini dijeceze ili redovničke provincije, dok je crkvena muzejska zbirka zbirka pojedinih župa i samostana, odnosno tzv. regionalna muzejska zbirka (depandansa središnjeg dijecezanskog ili provincijalnog muzeja). Ipak, sukladno članku 5. navedene Uredbe, niti jedan crkveni muzej ili zbirka nije samostalna pravna osoba (tj. samostalna crkvena ustanova) nego je ustrojstvena jedinica biskupskih ordinarijata, odnosno uprave redovničke provincije, koja obavlja muzejsku djelatnost te nije upisana $\mathrm{u}$ Evidenciju pravnih osoba Katoličke Crkve u Republici Hrvatskoj pri Ministarstvu uprave.

Registar muzeja, zbirki i riznica u vlasništvu vjerskih zajednica vodi Muzejski dokumentacijski centar (MDC) u Zagrebu. U dostupnim se informacijama Registra navodi kako su, uz muzeje i galerije, zbirke vjerskih zajednica najvažniji čuvari pokretne kulturne baštine u Hrvatskoj (http://mdc.hr/hr/mdc/ zbirke-fondovi/registri/), pa je projekt izrade Registra muzeja, zbirki i riznica u vlasništvu vjerskih zajednica od iznimne važnosti s obzirom na to da mnoge vjerske zajednice čuvaju izuzetne primjerke kulturno-povijesnog naslijeđa Republike Hrvatske, a nisu u nadležnosti države. Registar sadrži podatke o 174 takva vjerska objekta.

\section{DOMINIKANSKI MUZEJI U REPUBLICI HRVATSKOJ}

\subsection{Dominikanski samostani u Republici Hrvatskoj}

S obzirom na svoje opće i specifične ciljeve, dominikanski samostani kao neprofitne organizacije u Republici Hrvatskoj djeluju kao pravne osobe. U djelovanju čiji cilj je rad za dobro pojedinaca, kao i za opće dobro, surađuju s brojnim neprofitnim i profitnim organizacijama. Za ljude koji se okupljaju oko dominikanaca organiziraju se brojne aktivnosti, primjerice: duhovne obnove i duhovna 
pomoć, molitveni susreti, edukacija i informiranje djece, mladih i odraslih (župna kateheza), razni oblici okupljanja i druženja mladih i odraslih, organiziraju se hodočašća, izdaje se teološka i duhovna literatura te audiovizualna građa, organiziraju se razne priredbe zabavnog i kulturnog sadržaja, humanitarne akcije, izložbe, koncerti i slično. Organiziranjem znanstvenih i društvenih tribina, izdavaštvom te kulturno-umjetničkim događajima utječu na promicanje vjerskih i društvenih vrednota hrvatskoga naroda.

Pitanje položaja vjerskih zajednica u Republici Hrvatskoj uređeno je Zakonom o pravnom položaju vjerskih zajednica, a upisuju se u Evidenciju vjerskih zajednica koju vodi Ministarstvo uprave Republike Hrvatske. Isto tako, u navedenu Evidenciju mogu se upisati i organizacijski oblici vjerskih zajednica i zajednice vjerskih zajednica. Prema Obavijesti o razvrstavanju poslovnog subjekta prema NKD-u 2002. Državnog zavoda za statistiku Republike Hrvatske - koja je donesena na temelju članka 5. stavka 1. i 2. i članka 7. stavka 1. Zakona o nacionalnoj klasifikaciji djelatnosti (Narodne novine, broj 98/94) - Hrvatska dominikanska provincija Navještenja B. D. Marije, kao krovna institucija Reda propovjednika u Republici Hrvatskoj, pravno je ustrojena kao „Ostale organizacije“ s naznakom djelatnosti „Djelatnosti vjerskih organizacija“ te kao pravna osoba ima svoj matični broj i osobni identifikacijski broj (OIB).

Svaki osnovani samostan, koji je dio Hrvatske dominikanske provincije - ali po pravnom ustroju samostana Reda samostalno donosi odluke - evidentiran je u Evidenciji pravnih osoba Katoličke Crkve u Republici Hrvatskoj pod evidencijskim brojem, uz ostale informacije o pravnoj osobi te predstavlja specifičnu vrstu neprofitnih organizacija. Sukladno Ugovoru između Svete Stolice i Republike Hrvatske, Zakoniku kanonskoga prava (Berljak, Blažević, Kos, Starić, Škalabrin i Večković, 1996, br. 634 - 636) i Knjizi konstitucija i naredbi braće Reda propovjednika ${ }^{1}$ (Hrvatska dominikanska provincija, 2016) samostanski prior ima pravo odlučivati o imovini u vlasništvu pojedinog samostana, odnosno samostanski starješina ako se radi o kući.

Prema tome, ako se radi o kulturnoj baštini koju pojedini samostan čuva, na samostanskom prioru je i neposredna briga o umjetninama koje su u vlasništvu samostana. Dominikanci su, ne samo na razini Reda nego i na razini pojedine provincije, dužni čuvati kulturnu baštinu i o njoj voditi posebnu brigu. Prema Statutu Hrvatske dominikanske provincije određeno je da se sastavi posebno Vijeće za umjetnine čija je zadaća vođenje brige o kulturnim i umjetničkim dobrima

${ }^{1}$ Konstitucije (lat. Constutiones), uredbe, zakonska pravila i propisi neke redovničke zajednice. Sadrže temeljne odredbe o upravljanju zajednicom te životu u njoj. „Knjiga konstitucija i naredbi braće Reda propovjednika“ - knjiga je pravila i naredbi dominikanskoga reda koja donosi opis ustrojstva i načina upravljanja u Redu te pravila koja dominikanci moraju poštivati i upute za život u zajednici (Buljat, Gavrić, Vuco, Farkaš i Novina, 2012, str. 141). 
Provincije, kao i da se treba posvetiti osobita pozornost čuvanju kulturne baštine (zgrada, knjiga i umjetnina) (Hrvatska dominikanska provincija, 2016, br. 13 i $46 \S$ 2.). U navedenom dokumentu određeno je i da je potrebno dostaviti Provincijalatu izvještaj o stanju „umjetničkih, povijesnih i drugih vrijednih predmeta“ (br. 20). Ipak, s obzirom na dostupnu dokumentaciju i podatke iz Arhiva Provincije, čini se da ta izvješća nisu redovito dostavljana, a mnoga su djela i u posudbi stoga ne postoje sveobuhvatni popisi pokretne i nepokretne kulturne baštine svih dominikanskih samostana u Republici Hrvatskoj.

U skladu s općom misijom Reda propovjednika (,,spoznavanje istine i priopćavanja te istine drugima“ radi ,propovijedanja i spašavanja duša“ (Prvobitne Konstitucije Reda propovjednika, prolog)), misija dominikanskih samostana osim pružanja duhovne pomoći svojim korisnicima i kupcima (prodaja krunica i izdanja Dominikanske naklade Istine i slično) jest i obrazovanje. Dio obrazovanja zasigurno predstavlja i upoznavanje s kulturno-umjetničkim blagom dominikanskih samostana koje svjedoči o povijesti i kulturi Hrvata na ovim prostorima, kao i knjižnice, muzeji i muzejske zbirke koje su u vlasništvu dominikanskih samostana.

\subsection{Kulturno-umjetnička baština dominikanskih muzeja u Republici Hrvatskoj}

Od 13. stoljeća do danas dominikanski red, odnosno Red propovjednika (lat. Ordo Praedicatorum), gradio je samostane, građevine i crkve, a neke se smatraju pravim spomenicima graditeljstva (primjerice, crkva Sv. Marije od Milosti (Santa Maria delle Grazie) u Milanu, poznata i po „Posljednjoj večeri“ Leonarda da Vincija, koja je na UNESCO-vu popisu svjetske baštine (Buljat i sur., 2012)). Svaki samostan čuva neprocjenjivo kulturno-umjetničko blago i svjedoči o neizmjernom utjecaju dominikanaca na kulturu i život naroda s kojima su bili u doticaju za vrijeme osamstoljetnoga postojanja i djelovanja Reda.

Buljat i sur. (2012) ističu kako je na hrvatskim prostorima Red imao 81 samostan, od čega se na području današnje Republike Hrvatske nalazio 61 (usp. Fisković, 2011, str. 10). Danas Hrvatska dominikanska provincija ima 13 samostana i kuća, i to u sljedećim gradovima: Dubrovnik, Split, Trogir, Gruž, Bol, Stari Grad, Korčula, Zagreb, Rijeka; Klopče (Bosna i Hercegovina); Žalec i Petrovče (Slovenija). Hrvatski dominikanci su umjetnička djela naručivali od poznatih umjetničkih radionica i velikih majstora te su za gradnju i opremanje crkava i samostana angažirali mnoge domaće i strane graditelje, slikare i kipare (Fisković, 2011). Unatoč burnoj povijesti u kojoj su mnoge dominikanske crkve i samostani bili uništeni, a umjetnine nestale, danas su ipak mnogi od njih male umjetnič- 
ke galerije koje čuvaju slike, skulpture, rukopise, kodekse i inkunabule, knjižnice, bogato urešena misna ruha, skupocjene relikvije, liturgijsko posuđe i nakit. Predstavljaju neprocjenjivo kulturno i umjetničko blago te su neizbrisiv znak doprinosa dominikanaca hrvatskoj kulturnoj baštini (Fisković, 2011; Buljat i sur., 2012). U Zagrebu je 2007./2008. upriličena izložba „Dominikanci u Hrvatskoj“, u Galeriji Klovićevi dvori, na kojoj su umjetnine dominikanskih samostana bile izložene i predstavljene javnostima.

Važno je istaknuti činjenicu da se za mnoge vrijedne izloške crkvenih i muzejskih zbirki ne zna kako su dospjele u pojedine crkve i samostane ili ne postoje pisani podaci o pojedinoj umjetnini, stoga je teško odrediti njihovo podrijetlo. U Registru muzeja, zbirki i riznica u vlasništvu vjerskih zajednica Republike Hrvatske Muzejskog dokumentacijskog centra mogu se naći osnovni podaci o zbirci, opis te kontakt-podaci za zbirke u vlasništvu dominikanskih samostana, i to pod sljedećim nazivima: „Muzej dominikanskog Samostana sv. Dominika“ (Dubrovnik), „Zbirka samostana otaca dominikanaca“ (Trogir), „Muzejska zbirka samostana dominikanaca, Stari Grad (otok Hvar)“, „,Muzejska zbirka dominikanskog samostana, Bol (otok Brač)“ te „Knjižnica 'Hijacint Bošković', Zagreb“.

\subsubsection{Muzej dominikanskog Samostana sv. Dominika}

Muzej najstarijeg dominikanskog samostana na području Republike Hrvatske, osnovanog 1225. g. u Dubrovniku, sadrži iznimno bogat postav raznovrsnih predmeta koji svjedoče o djelovanju dominikanaca na dubrovačkom prostoru. Otvoren je 1970., a današnji izložbeni postav potječe iz 1986. godine. Prema podacima registra MDC-a, u muzeju su izložena kapitalna djela hrvatske renesanse - radovi tzv. „dubrovačke slikarske škole“ 15. i 16. stoljeća ${ }^{2}$ i brojni radovi stranih umjetnika $^{3}$. U zasebnom prostoru izložena su djela suvremenoga hrvatskog slikarstva ${ }^{4}$. Dio postava predstavlja i zbirka zavjetnih darova od zlata, srebra i dragog kamenja, nakit dubrovačkog plemstva, moćnici i relikvije ${ }^{5}$.

2 Ističu se poliptih Lovre Dobričevića „Bogorodica s Djetetom i svecima“, djela Nikole Božidarevića: „Navještenje Marijino“, triptih „Bogorodica s Djetetom i četiri sveca“, poliptih „Bogorodica s Djetetom, sv. Grgurom i sv. Martinom“ te triptih Mihajla Hamzića s prikazom sv. Nikole i svetaca.

3 Npr. oltarna pala „Sv. Magdalena sa sv. Vlahom, arkanđelom Rafaelom s Tobijom i donatorom“ (Tiziano i pomoćnici) iz 1550. g. Izložene su i italokretske ikone te radovi Vasarija i Lorenza di Credija.

${ }_{4}$ Primjerice, oltarska pala „Čudo sv. Dominika“, rad Vlahe Bukovca, kao i radovi dubrovačkog slikara Iva Dulčića.

5 Od relikvija se ističu prst sv. Dominika, donesen iz Bologne 1233. g., relikvija mađarskog kralja sv. Stjepana te križ srpskog kralja Stefana Uroša II. Milutina. 
U sklopu samostana se nalazi jedna od najstarijih (i najbogatijih) knjižnica koja posjeduje 240 inkunabula i 220 rukopisa. Knjižnica dubrovačkih dominikanaca ubraja se među najveće povijesne knjižnice dominikanskoga reda uopće. (Pelc u: Fisković, 2011, str. 246), a javnostima je otvorena 1501. godine uz pomoć Dubrovačkog senata (Buljat, 2019). Posjeduje 24 srednjovjekovna rukopisa, od kojih je više od polovice iluminirano (Fisković, 2011), bule raznih papa, kao i važne dokumente. Rukopisi i knjige su u samostan dospijevali na različite načine, većinom nabavkom redovnika pri odlasku na studij u velika sveučilišna središta, kao i različitim donacijama. Prema Pelcu (u Fisković, 2011, str. 246) jedna je od najbolje očuvanih knjižnica Reda, a obnovom je pretvorena u suvremenu knjižnicu s odgovarajućom pohranom knjižne i rukopisne građe te opremom za njezino korištenje.

\subsubsection{Zbirka samostana otaca dominikanaca u Trogiru}

Zbirka samostana otaca dominikanaca u sklopu Samostana sv. Dominika u Trogiru, osnovanog 1265. g., sadrži vrijedne slike, drvene predmete i liturgijske metalne predmete iz razdoblja od prve polovice 15. do 19. stoljeća, a crkva u sklopu Samostana čuva vrijedne slike i oltarne pale, kamene predmete i reljefe, liturgijske i ukrasne predmete te bogato crkveno ruho ${ }^{6}$. Postavu važnu vrijednost daju i liturgijski metalni predmeti, primjerice srebrni pozlaćeni gotički relikvijari iz 15 . stoljeća, koji su se prije nalazili u dominikanskoj crkvi Sv. Križa na Čiovu.

\subsubsection{Muzejska zbirka dominikanskog samostana u Bolu (otok Brač)}

Muzejska zbirka u Samostanu Sv. Marije Milosne u Bolu, koji je osnovan 1475. godine, sadržava umjetničke i arheološke predmete, liturgijsko posuđe iz razdoblja 16. - 19. stoljeća, drvenu plastiku i slike iz razdoblja 15. - 19. stoljeća te crkveno ruho. Bužančić (u Fisković, 2011) ističe kako zbirka sadrži i vrijedne

${ }^{6}$ Iznimno vrijedne slike: šestodijelni poliptih Blaža Jurja Trogiranina iz prve polovice 15 . st.; renesansna oltarna pala „Gospa s djetetom i svecima“ s kraja 16. st.; „Obrezanje Kristovo u hramu“, venecijanskoga ranobaroknog slikara Palme Mlađeg te slika „Gospa od Ružarija“ iz radionice Bassano s prikazom Lepantske bitke (kraj 16. st./početak 17. st.). Ističe se medaljon „Gospa s Djetetom i sv. Ivanom Krstiteljem“. Od drvene plastike „Golgota“ iz 16. st., a od kamene plastike „Madona Dolores“ iz 15. st. te uzidani triptih s likovima sv. Ivana Trogirskog, sv. Jere i sv. Lovre iz kruga renesansnog kipara Nikole Firentinca. 
knjige (među kojima i one na glagoljici), numizmatičku kolekciju (s vrlo rijetkim primjerima antičkog novca iz 2. st. pr. Kr.) te arhivsku građu iz razdoblja 15. - 18. stoljeća. Isto tako samostan ima i vrijednu knjižnicu s knjigama i rukopisima koje potječu iz razdoblja od 15. do 18. stoljeća, te brojne rukopise i raritete.

Prema Bužančiću (u Fisković, 2011, str. 274), smatra se da je bolska muzejska zbirka jedna od bogatijih među zbirkama podmorskih arheoloških spomenika s brojnim keramičkim posuđem serijske provincijalne izrade. Bužančić navodi da se ovdje nalazi i vrlo rijedak tip kasnoantičkog sarkofaga obilježen znakom križa tipične bračke produkcije (u Fisković, 2011, str. 274). Ulomci oltarne pregrade predromaničke crkve sv. Ivana i Teodora iz 9. stoljeća (sagrađena na temeljima antičke građevine iz 6. stoljeća) osim oltarnih ukrasa sadrže i vrijedne starohrvatske pletere koji su jedini takav primjerak pronađen na otoku Braču, pa time predstavlja i iznimnu dragocjenost zbirke. Muzejska zbirka sadrži i bogatu arhivsku građu o životu samostana, antifonare, graduale, numizmatičku zbirku, glagoljašku baštinu (npr. misal iz 14. st.). Od vrijedne kolekcije može se istaknuti oltarna pala „Bogorodica sa svecima“ iz radionice Jacopa Tintoretta te renesansni relikvijar s likom Krista i Svete obitelji, rad mletačkoga renesansnog slikara iz 16. stoljeća (Fisković, 2011).

Budući da se muzej u Bolu obnavlja (već osam godina), građa nije popisana, odnosno u izradi je popis umjetnina, a u planu je i novi postav muzeja, tzv. „Gospino zlato“: zavjetni darovi bolskih vjernika, od kojih neki datiraju i iz vremena osnivanja Samostana u Bolu (Buljat, 2019).

\subsubsection{Muzejska zbirka samostana dominikanaca, Stari Grad (otok Hvar)}

Zbirka se nalazi u sklopu Samostana sv. Petra Mučenika, osnovanog 1481. godine. Među više od 2000 arheološko-povijesnih predmeta sadrži arheološku i prirodoslovnu građu, ukrasne predmete, misno ruho i posuđe, vrijedna slikarska i kiparska djela i inkunabule. Stalni postav muzeja s više od 400 eksponata datira od 1989. godine i predstavlja iznimnu kulturno-umjetničku baštinu, ne samo za dominikance već i za otok Hvar i Republiku Hrvatsku.

Prema opisu zbirke u registru MDC-a, od prirodoslovne građe čuvaju se fosili riba. Izloženi su paleolitički, grčki i rimski kameni predmeti te keramika, a veliku povijesnu vrijednost imaju arheološki nalazi iz vremena Farosa, od kojih neki pripadaju najstarijim pisanim spomenicima na tlu Republike Hrvatske. Iz grčkog razdoblja od 4. st. pr. Kr. izloženi su zavjetni, nadgrobni i međašni spomenici. Iz razdoblja staroga Rima potječu i vrijedne nadgrobne stele te reljef starorimskog trgovačkog broda u mramoru. U postavu su i rimski mozaici i staklo, kao i 
rimsko-bizantski ukrasni predmeti. Značajna je zbirka starohrvatskih kamenih ulomaka. Posebne eksponate čine pečati i drugi predmeti povezani s pjesnikom Petrom Hektorovićem. Zatim, crkveno ruho, srebro i zavjetni darovi te muransko staklo. Među slikama je najvrjednija „Oplakivanje Krista“, Jacopa Tintoretta te tri nepotpisane slike koje se pripisuju Palmi Mlađem. Vrijedno je i raspelo iz 1703. godine.

Knjižnica u sklopu samostana sadrži brojne rukopise iz 15. stoljeća te druge vrijedne knjige i dokumente. Čuvaju se i manuskripti te inkunabule, među kojima i vrlo poznati kantual s kraja 14. i početka 15. stoljeća koji sadrži prve notne zapise u Republici Hrvatskoj, a čija je vrijednost značajna za europsku kulturu općenito (Buljat, 2019).

\subsubsection{Knjižnica „Hijacint Boškovič“ u Zagrebu}

Knjižnica „Hijacint Bošković“, smještena u Samostanu Kraljice svete Krunice u Zagrebu, središnja je knjižnica Hrvatske dominikanske provincije. Osnovana je kad i samostan, 1927. godine te je kao privatna knjižnica namijenjena za korištenje prvenstveno dominikancima, s mogućnošću javnog pristupa (studenti i profesori filozofije i teologije, pastoralni djelatnici i zainteresirani vjernici). Prema dostupnim informacijama na internetskim stranicama Provincije knjižnica sadrži brojna izvorna djela, a zbog svoje važnosti uvrštena je u spomeničke knjižnice. U njoj se nalazi oko 40000 knjiga i više od 200 naslova časopisa na hrvatskom i stranim jezicima. Najveći dio građe čine knjige i časopisi iz područja filozofije, teologije, religije i humanističkih znanosti. Čuvaju se i rijetke knjige iz 16., 17. i 18. stoljeća (oko 1000 naslova), poput Aristotelove „Filozofija prirode“ iz 1531. g., „Komentari Domenika“ iz 1598. i komplet „Summae Theologiae“ Tome Akvinskog iz 1691. godine. Knjige su u Zagreb uglavnom dopremljene iz samostana dominikanaca u Šibeniku, koji je prestao s djelovanjem, a knjižni fond se prvenstveno povećava iz ostavštine preminulih članova Provincije, napuštenih samostana te nabavom novih izdanja. 
Đ. OZRETIĆ DOŠEN, A. BULJAT: Marketing usluga dominikanskih muzeja u Republici Hrvatskoj EKONOMSKI PREGLED, 72 (2) 224-248 (2021)

\section{IZVIĐAJNO ISTRAŽIVANJE MARKETINGA USLUGA DOMINIKANSKIH MUZEJA}

Većina kulturnih proizvoda i/ili usluga može se definirati kao složena, pogotovo kada njihova konzumacija odnosno doživljaj zahtijevaju specifično znanje ili se oslanjaju na apstraktne pojmove čije uvažavanje zahtijeva posebnu sposobnost (Colbert i Ravanas, 2018). Uloga marketinga u muzeju je ... ponuditi posjetiteljima najveću moguću vrijednost za trošak posjete muzeju. (Kotler, Kotler i Kotler, 2008, str. 21), odnosno Muzeji koriste marketing jer im nudi teoriju, alate $i$ vještine koji im omogućuju povećanje broja posjetitelja, izgradnju odnosa i povećanje prihoda. (Kotler i sur., 2008, str. 2). Osim mjesta kulture i umjetnosti, muzeji su mjesta gdje se posjet pretvara u doživljaj/iskustvo, pa se postavlja pitanje što u dominikanskim muzejima, osim posebnog ambijenta samostana koji pruža izvorni doticaj s poviješću gdje je ona i nastajala, taj posjet čini takvim da se on doživi kao iskustvo, kao bitni sastavni element usluge. Polazna je pretpostavka istraživanja da dominikanski samostani u Republici Hrvatskoj, čijim je muzejima i galerijama primarni cilj obrazovanje i očuvanje kulturno-umjetničke baštine, ne koriste dovoljno elemente marketinga kako bi oblikovali i ponudili svoje usluge.

\subsection{Metodologija}

Provedeno je izviđajno, kvalitativno istraživanje. Podaci su prikupljeni iz sekundarnih i primarnih izvora, a korištene su metode proučavanja arhivske građe i intervjua. Prikupljeni podaci su analizirani, komparirani, sintetizirani i interpretirani.

Podaci o marketinškim aktivnostima dominikanskih muzeja i muzejskoj građi prikupljeni su korištenjem dostupne dokumentacije dominikanskih samostana (samostanski arhivi) i internetskih stranica, Muzejskog dokumentacijskog centra, literature o umjetninama dominikanskih samostana te radijske emisije o dominikanskim muzejima u Republici Hrvatskoj. Izvore sekundarnih podataka čini i znanstvena i stručna literatura iz područja marketinga usluga, neprofitnih, religijskih organizacija, marketinga u kulturi i umjetnosti, povijesti kulturne baštine i povijesti Reda propovjednika na području Republike Hrvatske te internetske stranice Hrvatske dominikanske provincije. Primarni podaci o muzejskoj građi i marketinškim aktivnostima prikupljeni su u individualnim razgovorima s dominikancima iz dubrovačkog, trogirskog, bolskog i starogradskog samostana koji su, s obzirom na prava i obveze koje im po službi pripadaju, zaduženi za brigu o pojedinom samostanskom muzeju, odnosno muzejskoj zbirci (starješine kuća i priori 
samostana). Intervjuiranje starješina kuća i priora samostana provela je jedna od autorica rada. Razgovori su trajali između 20 i 30 minuta, a vođeni su uz podsjetnik za intervju koji je obuhvaćao sljedeće teme - pitanja:

1. Koje povijesno razdoblje obuhvaća postav te što čini glavni sadržaj muzejske građe, odnosno knjižnice, a koji je dostupan javnostima?

2. Nudi li samostan dodatne usluge osim posjeta muzeju? Koje i kakve, tko te kako se o njima odlučuje?

3. Na koji način se formira cijena ulaznica za muzej, koji je njezin iznos?

4. Koje je radno vrijeme muzeja/knjižnice te koliko se ono (ne)prilagođava potražnji za posjetom muzeju?

5. Kako muzej komunicira s posjetiteljima i javnošću? Koje su dodatne napomene važne vezane uz djelovanje i posjet zainteresiranih muzeju/knjižnici?

Opsežniji intervju proveden je s priorom dominikanskog Samostana sv. Dominika u Dubrovniku, s kojim se razgovaralo i o sljedećem: broju i omjeru između stranih i domaćih posjetitelja muzeja; pristupima prezentaciji postava $\mathrm{u}$ muzejskom prostoru, brizi o posjetiteljima tijekom posjeta, detaljnijim komunikacijskim aktivnostima muzeja.

\subsection{Rezultati istraživanja}

U tablici 1. sumirane su informacije o sadržaju muzejskih zbirki samostana, ponudi usluga dostupnih za javnosti, kao i uvjetima korištenja. Potom su u dijelu 4.2.1. opisno prikazani rezultati istraživanja po elementima marketinškog miksa muzejske usluge, a u dijelu 4.2.2. detaljnije je analiziran pristup marketingu usluga u muzeju Samostana sv. Dominika u Dubrovniku. 


\section{Tablica 1.}

\section{PREGLED MUZEJSKIH USLUGA DOMINIKANSKIH SAMOSTANA U REPUBLICI HRVATSKOJ}

\begin{tabular}{|c|c|c|c|}
\hline Muzejska zbirka & Sadržaj muzejske zbirke i razdoblje & $\begin{array}{l}\text { Usluge dostupne } \\
\text { javnostima }\end{array}$ & $\begin{array}{l}\text { Cijena ulaznica i } \\
\text { radno vrijeme }\end{array}$ \\
\hline $\begin{array}{l}\text { Muzej Samostana } \\
\text { sv. Dominika - } \\
\text { Dubrovnik }\end{array}$ & $\begin{array}{l}\text { Slike; zbirka zavjetnih darova od } \\
\text { zlata, srebra i dragog kamenja; nakit; } \\
\text { moćnici; relikvije. } \\
\text { Knjižnica: srednjovjekovni rukopisi; } \\
\text { bule i važna dokumentacija. } \\
\text { Razdoblje: } 13 . \text { st. - 20. st. }\end{array}$ & $\begin{array}{l}\text { Razgled crkve } \\
\text { sv. Dominika i } \\
\text { samostanskog klaustra. } \\
\text { Posjet knjižnici moguć } \\
\text { je uz prethodnu najavu. }\end{array}$ & $\begin{array}{l}\text { Odrasli: } 30,00 \mathrm{kn} \\
\text { Mladi: } 20,00 \mathrm{kn} \\
\text { Djeca do } 14 \mathrm{~g} . \\
\text { besplatno } \\
\text { 1. } 5 .-1.10\end{array}$ \\
\hline $\begin{array}{l}\text { Zbirka Samostana } \\
\text { sv. Dominika - } \\
\text { Trogir }\end{array}$ & $\begin{array}{l}\text { Slike; drveni predmeti i liturgijski } \\
\text { metalni predmeti; crkveno ruho. } \\
\text { Razdoblje: prva polovica } 15 . \text { st. }-19 \text {. } \\
\text { st. }\end{array}$ & $\begin{array}{l}\text { Razgled crkve } \\
\text { sv. Dominika i } \\
\text { samostanskog klaustra. } \\
\text { Suvenirnica s prigodnim } \\
\text { predmetima. }\end{array}$ & $\begin{array}{l}20,00 \mathrm{kn} \text { po osobi } \\
\text { Ljetni period, ostalo } \\
\text { po najavi }\end{array}$ \\
\hline $\begin{array}{l}\text { Muzejska zbirka } \\
\text { Samostana } \\
\text { sv. Petra } \\
\text { Mučenika- Stari } \\
\text { Grad }\end{array}$ & $\begin{array}{l}\text { Arheološki predmeti; prirodoslovna } \\
\text { građa; ukrasni predmeti; misno ruho i } \\
\text { posuđe; slikarska i kiparska djela. } \\
\text { Knjižnica: inkunabule; vrijedne knjige } \\
\text { i dokumenti. } \\
\text { Razdoblje: } 4 \text {. st. pr. Kr. - 20. st. }\end{array}$ & $\begin{array}{l}\text { Razgled klaustra } \\
\text { i samostanskog vrta. }\end{array}$ & $\begin{array}{l}20,00 \text { kn po osobi } \\
\text { Proljeće - jesen }\end{array}$ \\
\hline $\begin{array}{l}\text { Muzejska zbirka } \\
\text { Samostana } \\
\text { sv. Marije } \\
\text { Milosne - Bol }\end{array}$ & $\begin{array}{l}\text { Umjetnički i arheološki predmeti; } \\
\text { liturgijsko posuđe; drvena plastika; } \\
\text { crkveno ruho; numizmatička kolekcija; } \\
\text { vrijedne knjige i arhivska građa. } \\
\text { Razdoblje: } 2 \text {. st. pr. Kr. - 18. st. }\end{array}$ & $\begin{array}{l}\text { Organizacija grupnih } \\
\text { posjeta preko turističkih } \\
\text { agencija. } \\
\text { Muzej trenutno nije } \\
\text { dostupan javnostima } \\
\text { zbog renoviranja } \\
\text { knjižnice. }\end{array}$ & $\begin{array}{l}10,00 \text { kn po osobi } \\
\text { Proljeće - jesen i po } \\
\text { dogovoru }\end{array}$ \\
\hline $\begin{array}{l}\text { Knjižnica } \\
\text { „Hijacint - } \\
\text { Bošković““ - } \\
\text { Zagreb }\end{array}$ & $\begin{array}{l}\text { Knjige, časopisi i rukopisi te brojna } \\
\text { izvorna djela. } \\
\text { Razdoblje: } 16 . \text { st. do danas }\end{array}$ & $\begin{array}{l}\text { Knjižnični katalog } \\
\text { online. } \\
\text { Trenutno nije omogućen } \\
\text { pristup javnostima zbog } \\
\text { renoviranja knjižnice } \\
\text { i revizije knjižničnog } \\
\text { fonda. }\end{array}$ & $\begin{array}{l}\text { Besplatno } \\
\text { Prema dogovoru }\end{array}$ \\
\hline
\end{tabular}




\subsubsection{Marketinški miks usluge dominikanskih muzeja u Republici Hrvatskoj}

Marketinški miks neizostavan je i kritičan koncept u planiranju i provedbi marketinških aktivnosti. McLean (1994) je među prvima identificirala elemente marketinškog miksa usluge muzeja navodeći sedam elemenata: proizvod, cijenu, distribuciju, promociju, ljude, procese i fizičko okruženje. U nastavku su opisani, na temelju istraživanja utvrđeni, elementi marketinškog miksa muzeja dominikanskih samostana:

1. Proizvod / usluga - dominikanski muzeji nude uslugu posjeta muzeju, knjižnici (u pojedinim muzejima uz mogućnosti korištenja dijela građe), crkvi i klaustru samostana kojom se stječe znanje (informiranje, spoznaja) i iskustvo (doživljaj ambijenta i inventara muzeja). Od dodatnih usluga, u ograničenom broju muzeja nudi se prodaja predmeta u suvenirnici.

2. Cijena - za posjet dominikanskom muzeju, odnosno muzejskoj zbirci, potrebno je kupiti ulaznicu. U pojedinim muzejima cijene ulaznica su prilagođene dobi posjetitelja (za djecu i mlade, za odrasle) te veličini grupe (popust za određeni broj osoba), ili pak načinu plaćanja (gotovina ili uplata na račun). Određivanje cijena usluga uvijek je potrebno promatrati iz ekonomske i psihološke perspektive jer cijena održava vrijednost usluge za korisnika, pokazatelj je kvalitete i čimbenik izgradnje i održavanja imidža pružatelja (Ozretić Došen, 2010). Stoga je određivanje cijena ulaznica iznimno važan aspekt, u pojedinim slučajevima kompleksan i zahtjevan. Primjerice, u Samostanu u Bolu, s obzirom na broj (uglavnom stranih) posjetitelja, cijena ulaznice od $10,00 \mathrm{kn}$ po osobi ne zadovoljava potrebe za financijskom pomoći u podmirivanju osnovnih fiksnih troškova (režije, honorar osoblja i slično), kamoli za brigu o kulturno-umjetničkom blagu.

3. Distribucija - usluga dominikanskih muzeja odnosi se na fizičko okruženje muzeja, odnosno lokaciju svakog pojedinog samostana. Usluga se može koristiti jedino na samoj lokaciji (ne postoji virtualni posjet nijednom dominikanskom muzeju).

4. Promocija - nažalost, dominikanski muzeji ne vode osobito računa o marketinškoj komunikaciji, što se može uočiti i pregledavanjem internetskih stranica (Provincije, pojedinog samostana). Čak se na internetskim stranicama turističkih zajednica (npr. TZ Dubrovnik; TZ Staroga Grada; TZ Bol) može naći više informacija o samostanu, muzejskoj zbirci i radnom vremenu pojedinog muzeja (ponekad i pogrešnih) ili detaljima njihovih postava. Od navedenih jedino Samostan sv. Petra Mučenika ima vlastitu internetsku stranicu (http://www.dsspm.hr/) s detaljima o samostanu i 
muzeju. Pojedini samostani (ne svi) imaju katalog postava samostanskog muzeja s opisima, kao i vodiče u obliku manjih preklopnica.

5. Ljudi - zaposlenici i redovnici u samostanima koji brinu o muzejima i u izravnom su kontaktu s posjetiteljima čine važan dio usluge muzeja. Nažalost, nerijetko je slučaj da oni koji rade u muzejima dominikanskih samostana nemaju dovoljno znanja ni kompetencija za vođenje muzeja, kao ni za (dodatno) informiranje posjetitelja. S obzirom na to da su većina posjetitelja stranci, i to uglavnom u turističkim središtima Republike Hrvatske, zaposlenici bi trebali voditi posebnu brigu ne samo o povijesnim činjenicama pojedinog izloška već i o znanju i učenju stranih jezika.

6. Procesi - muzeji se međusobno razlikuju pa je i svaka usluga dominikanskog muzeja različita s obzirom na različitost mjesta (samostana), vremena i ljudi (zaposlenici) uključenih u proces te ostalih elemenata (heterogenost usluge).

7. Fizičko okruženje - dominikanski muzeji su u povlaštenom položaju što se ovoga elementa marketinškog miksa tiče s obzirom na to da se nalaze u sklopu zajednica gdje redovnici žive i djeluju, uz (ili unutar) konkretne građevine u kojima je povijest kulturno-umjetničkog naslijeđa nastajala. Osim navedenog, dominikanski samostani nalaze se uz gradska središta, u važnim turističkim destinacijama. Potrebno je usmjeriti više pozornosti na isticanje upravo te konkurentske prednosti kako bi se privuklo više posjetitelja, i to ne samo stranih nego i domaćih.

\subsubsection{Dominikanski muzej Samostana sv. Dominika u Dubrovniku}

Samostan sv. Dominika najstariji je samostan dominikanskoga reda u Republici Hrvatskoj, od iznimnog značaja za povijest i kulturu. Nalazi se u samom središtu stare jezgre grada, predstavlja veliko vjersko, spomeničko i turističko središte Dubrovnika u koji dolaze turisti iz cijeloga svijeta, a tijekom godine bilježi između 30000 - 50000 posjetitelja (udio domaćih posjetitelja $2-3 \%$ ), ovisno o pojedinoj sezoni. U dijelu 3.2.1. opisan je važan dio postava muzeja. Ovdje je pozornost usmjerena analizi usluga muzeja, a temeljem informacija prikupljenih u razgovoru sa samostanskim priorom. Razgovor je vodila jedna od autorica rada, u obliku polustrukturiranog intervjua, uz korištenje podsjetnika za intervju. Teme razgovora obuhvatile su sljedeće glavne dimenzije s pripadajućim kategorijama: a) usluge muzeja dominikanskog samostana; b) ulogu marketinga u ponudi i pružanju usluga te c) elemente marketinškoga miksa. Nalazi i analiza sadržaja odgovora na postavljena pitanja prikazani su sumarno u nastavku. 
Dominikanski muzej Samostana sv. Dominika u Dubrovniku, u koji se ulazi iz samostanskog klaustra, otvoren je za posjetitelje šest mjeseci tijekom kalendarske godine, od 1. svibnja do 31. listopada, s radnim vremenom od 8.30 do 16.30 . Uz svaki izložak muzejske zbirke nalazi se opis na hrvatskom i engleskom jeziku. Slike su osvijetljene posebnom rasvjetom, a ostali izlošci smješteni su u vitrinama. Osim muzejske zbirke, posjetitelji mogu vidjeti i samostanski klaustar s bunarom i starim dubrovačkim stablima naranči te samostansku crkvu sv. Dominika s velikim raspelom s Bogorodicom i sv. Ivanom Krstiteljem iz 14. st., autora Paola Veneciana. Posjetiteljima je za informacije na raspolaganju osoba zadužena za muzej. Uglavnom su to honorarno zaposlene visokoobrazovane osobe koje vode brigu o nesmetanom provođenju pojedinog posjeta, kao i očuvanju postava od eventualnih oštećenja, otuđenja i slično. Knjižnica u sklopu samostana dostupna je za posjetitelje, ali uz prethodnu najavu prioru samostana, radi želje za zaštitom i očuvanjem iznimno vrijednog knjižnog fonda.

Iz marketinške perspektive, u ponudi i pružanju usluga muzeja iznimno važan aspekt predstavlja ljudski čimbenik. Dominikanci posebnu pozornost pridaju izboru kako volontera tako i zaposlenika koji će voditi brigu o muzeju i posjetiteljima. Za ugled i reputaciju koje samostan kao institucija s dugogodišnjom svjetskom tradicijom ima, odabir adekvatne osobe koja odgovara standardima jedne takve (vjerske) zajednice ima iznimnu ulogu. Pritom valja naglasiti da obrazovanje zaposlenika nije prioritet (iako su visokoobrazovani). Bilo bi poželjno zapošljavati kompetentne osobe, profesionalce koji će obavljati posao kustosa. Redovnici koji žive i djeluju u samostanu također odražavaju ugled svoje zajednice, i Reda općenito, te mogu pružiti (kao dio usluge) poseban doživljaj povijesnoga ambijenta u ovakvom tipu spomeničkog graditeljstva u sklopu kojega se nalazi i muzej. Osim osobe koja je na usluzi posjetiteljima za sve vrste informacija o muzeju, uključivo opise pojedinih izložaka, postoje i vodiči-preklopnice u tiskanom obliku (na hrvatskom jeziku i na stranim jezicima) s pojašnjenjima izložaka.

Od dodatnih proizvoda nude se vodiči o muzeju u obliku knjige, na trima jezicima (engleskom, talijanskom i španjolskom) koji detaljnije opisuju pojedine izloške muzeja, kao i njihov povijesni kontekst. U prodaji je i monografija s izložbe „Dominikanci u Hrvatskoj“ održane u Galeriji Klovićevi dvori u Zagrebu 2007./2008. godine. Budući da se na omotu Monografije nalazi upravo pala Nikole Božidarevića koja se nalazi u samostanu, proizvod može biti prigodan dar ili uspomena na posjet Dubrovniku i dominikancima.

Kad se govori o elementu marketinškog miksa koji se odnosi na cijenu ulaznica za posjet muzeju, one su prilagođene dobi posjetitelja. Za odrasle je cijena $30,00 \mathrm{kn}$ po osobi, za mlade 20,00 kn po osobi, dok je za djecu do 14 godina ulaz besplatan. Dominikanci koriste strategiju prilagođavanja i snižavanja cijena, odnosno popuste za grupni posjet, ovisno o broju osoba. Što se tiče prodaje, ulaznice se 
mogu kupiti na ulazu u klaustar samostana za vrijeme radnoga vremena muzeja ili uplatom na račun. Međutim, na internetu ne postoji nikakva informacija o načinu kupnje niti cijenama. Za pretpostaviti je da se te informacije mogu dobiti pozivom na broj telefona ili usmenim prenošenjem informacija.

Osim što cijena usluge nije na odgovarajući način prezentirana niti su javnosti jasno upoznate s njome, čini se da usluga dominikanskog muzeja nema ni odgovarajuću promociju. Ako se krene od činjenice da samostan u vrijeme pisanja rada nema internetsku stranicu te na internetskoj stranici Provincije ne postoje informacije da samostan uopće ima muzej koji ima pristup javnostima, za zaključiti je da se eventualni posjetitelji moraju dobrano potruditi sami prikupiti informacije. Jedino se na internetskoj stranici turističke zajednice grada Dubrovnika nalazi kratka informacija o samostanu i muzeju. Od promotivnih aktivnosti mogu se istaknuti samo indirektni oblici komunikacije s javnostima - putem knjiga koje izdaje samostan ili Dominikanska naklada Istina, interneta (internetske stranice Provincije i TZ Dubrovnik; članci o dominikancima i Redu propovjednika na raznim portalima; objave na društvenim mrežama Provincije i pojedinih dominikanskih samostana) te prilikom organiziranja drugih kulturno-umjetničkih događaja koji se u samostanu i crkvi organiziraju (izložbe, koncerti i slično). Može se zaključiti da i ovdje prenošenje informacija usmenom predajom ima značajnu ulogu.

\section{ZAKLJUČAK}

Dominikanci su - u cijelome svijetu pa tako i u Republici Hrvatskoj - do danas ostavili snažan trag u vjerskom, kulturnom i znanstvenom životu. Red propovjednika u 800 godina svojega djelovanja dao je izniman doprinos u očuvanju kulturno-umjetničke baštine u Hrvatskoj, čemu svjedoče i vrijedne muzejske zbirke u sklopu dominikanskih samostana.

Neprofitne organizacije kojima je glavni cilj dobrobit društva u cjelini (ali i pojedinaca), sve se više koriste marketingom na način da u svojem djelovanju preuzimaju iz marketinga profitnog sektora elemente koji mogu pridonijeti poboljšanju njihovih usluga i djelovanja. Od 90-ih godina prošloga stoljeća u Republici Hrvatskoj marketing se sve više primjenjuje i u institucijama u kulturi i umjetnosti. Unatoč mnogim predrasudama o marketingu (primarno zbog njegova nerazumijevanja), praksa korištenja pojedinih elemenata marketinškog miksa može se uočiti i kod nekih vjerskih organizacija koje žele vrijednosti svoje organizacije prenijeti na ciljne skupine korisnika, ali i zadovoljili njihove potrebe (duhovne, društvene i sl.). Odgovarajuća primjena marketinga u vjerskim institucijama može poboljšati njihovo djelovanje u skladu misijom i vizijom organizacije te postavljenim ciljevima. 
Na primjeru primjene marketinga usluga dominikanskih muzeja u Republici Hrvatskoj - u skladu sa svrhom crkvenih muzeja i muzejskih zbirki Uredbe HBK o crkvenim muzejima i muzejskim zbirkama (čl. 6) - osim što se uočava potreba sustavnog rada na popisivanju i prikupljanju i ujednačavanju te čuvanju, znanstvenomu obrađivanju i predočavanju javnostima inventara pojedinih muzejskih zbirki, potrebno je raditi i na zapošljavanju i edukaciji onih koji se brinu o pojedinoj zbirki, i to ne samo u smislu očuvanja baštine nego i u marketinškom. To se osobito odnosi na promociju, kao i na ostale elemente marketinškog miksa za koje, za početak, nisu potrebna prevelika ulaganja. Dakako, ove je nalaze potrebno promatrati u svjetlu ograničenja provedenog kvalitativnog istraživanja koje se po svojoj prirodi temelji na specifičnim podacima, čija je vjerodostojnost tumačenja ovisna o njihovoj točnosti i potpunosti.

Osim navedenog, kao što dominikanci „osluškuju“ potrebe i želje korisnika svojih usluga duhovne naravi, potrebno je i praćenje njihovih motiva za korištenjem muzejskih usluga u aktualnom trenutku, kako bi se na odgovarajući način osmislila usluga samostanskih muzeja. Može se, prije svega, istaknuti potreba (interaktivne) prisutnosti na internetu (internetske stranice, društvene mreže), prilagođavanje radnoga vremena muzeja radnom vremenu zaposlenih osoba, kao i osmišljavanje interaktivnih aktivnosti u postavu (upotreba tehnoloških dostignuća, aplikacija i slično) za djecu i odrasle, a kako posjet samostanskom muzeju ne bi bio samo pasivno promatranje. Isto tako, doživljaj posjetitelja muzeja mogao bi se obogatiti uvođenjem glazbe kao dijela usluge. Primjerice, ponuda mogućnosti odabira slušanja liturgijske glazbe, izvornih napjeva i glazbe dominikanskoga reda u svijetu i u Hrvatskoj iz različitih razdoblja. Usluga bi se mogla unaprijediti i audiovizualnim projekcijama (djelomično ili u cijelosti) dokumentarnoga filma „Dominikanci u Hrvatskoj - prvih 800 godina“ scenarista i redatelja Krešimira Čokolića te drugih biblijskih tema. Velik je izazov pratiti trendove i zahtjeve korisnika vjerskih i usluga kulture i umjetnosti 21. stoljeća. Uz želju, trud i znanje moguće je uslugu dominikanskih muzeja osmisliti na način koji nije samo informativne i edukativne već i interaktivne prirode koja pruža poseban iskustveni doživljaj.

Buduća istraživanja su neophodna, a potrebno ih je usmjeriti i na stranu potražnje to jest na istraživanja posjetitelja dominikanskih muzeja te njima obuhvatiti, na primjer, istraživanje zadovoljstva posjetitelja, odnosno mjerenje kvalitete usluge koju pružaju dominikanski muzeji. 
Đ. OZRETIĆ DOŠEN, A. BULJAT: Marketing usluga dominikanskih muzeja u Republici Hrvatskoj EKONOMSKI PREGLED, 72 (2) 224-248 (2021)

\section{ZAHVALA}

Zahvaljujemo Hrvatskoj dominikanskoj provinciji Navještenja B. D. Marije za suradnju i omogućavanje pristupa dokumentaciji te informacijama o postavu i djelovanju samostanskih muzejskih zbirki.

\section{LITERATURA:}

1. Abreu, M. (2006). The brand positioning and image of a religious organisation: an empirical analysis. Int. J. Nonprofit Volunt. Sect. Mark., 11, 139-146. DOI: $10.1002 /$ nvsm.49

2. Berljak, M. Blažević, V., Kos, S., Starić, A., Škalabrin, N. i Večković, S., (Ur.) (1996). Zakonik kanonskoga prava s izvorima. Zagreb: Glas Koncila.

3. Buljat, A. (2019). Dominik - propovjednik milosti, Radio Marija, 26. 2. 2019. (audio-zapis)

4. Buljat, A., Gavrić, A. Vuco, J., Farkaš, M., i Novina, I.P. (Ur.) (2012). Sveti Dominik $i$ Red propovjednika (priručnik za državnu olimpijadu iz vjeronauka). Zagreb: Dominikanska naklada Istina.

5. Buljubašić, I., Borić, M. i Hartmann Tolić, I. (2016). The impact of promotion in creative industries - The case of museum attendance. Ekonomski vjesnik / Econviews, (29)1, 109-124.

6. Colbert, F. i Ravanas P. (2018). Marketing Culture and the Arts. Montreal: Carmelle and Rémi Marcoux Chair in Arts Management, HEC Montreal.

7. Cole, D. (2008). Museum marketing as a tool for survival and creativity: the mining museum perspective, Museum Management and Curatorship, (23)2, 177-192. DOI: 10.1080/09647770701865576

8. Einstein, M. (2008). Brands of Faith - Marketing Religion in Commercial Age. New York: Routlege.

9. Einstein, M. (2011). The Evolution of Religious Branding. Social Compass, (58)3, 331-338. DOI: $10.1177 \% 2 F 0037768611412138$

10. Fisković, I. (Ur.) (2011). Dominikanci u Hrvatskoj. Zagreb: Galerija Klovićevi dvori.

11. Forgas-Coll, S., Palau-Saumell, R., Matute, J. i Tarrega, S. (2017). How Do Service Quality, Experiences and Enduring Involvement Influence Tourists' Behavior? An Empirical Study in the Picasso and Miró Museums in 
Barcelona, The International Journal of Tourism Research, (19)2, 246-256 DOI:10.1002/jtr.2017

12. Hrvatska biskupska konferencija (2001). Uredba HBK o crkvenim muzejskim zbirkama, Đakovačka i Srijemska biskupija. Vjesnik Đakovačke i Srijemske biskupije, (129)1, 9-10.

13. Hrvatska dominikanska provincija (2016). Akti izborne Provincijske skupštine održane u Samostanu Sv. Marije Milosne u Bolu i Statut Hrvatske dominikanske provincije. Bol.

14. Hrvatska dominikanska provincija (2002). Knjiga konstitucija i naredbi braće Reda propovjednika. Zagreb.

15. Komarac, T. (2013). Marketing usluga zagrebačkih muzeja. Specijalistički poslijediplomski rad. Zagreb: Ekonomski fakultet - Zagreb.

16. Komarac, T., Ozretic-Dosen, D. i Skare, V. (2019). The Role of the Museum Shop: Eliciting the Opinions of Museum Professionals. International Journal of Arts Management, (21)3, 28-41.

17. Komarac, T., Ozretic-Dosen, D. i Skare, V. (2017). Understanding competition and service offer in museum marketing. Academia Revista Latinoamericana de Administración, (30)2, 215-230. DOI: 10.1108/ARLA-07-2015-0159

18. Kotler, N. G., Kotler, P. i Kotler, W. I. (2008). Museum marketing and strategy: designing missions, building audiences, generating revenue and resources. San Francisco: Jossey-Bass.

19. Maher, K. J., Clark, J. i Gambill Motley, D. (2011). Measuring Museum Service Quality in Relationship to Visitor Membership: The case of Children's Museum. Marketing Menagement, (13)2, 29-42.

20. McGraw, A. P., Schwartz, J. A. i Tetlock, P. E. (2012). From the Commercial to the Communal: Reframing Taboo Trade-offs in Religious and Pharmaceutical Marketing. Journal of Consumer Research, (39)June, 157173. DOI:10.1086/662070

21. McKercher, B. i du Cros, H. (2002). Cultural Tourism - the Parntership Between Tourism and Cultural Heritage Management. Binghamton NY: The Haworth Press.

22. McLean, F. (1994). Services Marketing: The Case of Museum. The Service Industries Journal, (14)2, 190-203. DOI: 10.1080/02642069400000022

23. McLean F. (2002). Marketing the museum. London: Taylor \& Francis.

24. Meler, M. (2003). Neprofitni marketing. Osijek: Ekonomski fakultet.

25. Mencarelli, R. i Pulh, M. (2012). Museoparks and re-enchantment of the museum visits: an approach centered on visual ethnology. Qualitative Market Research, (15)2, 148-164. https://doi.org/10.1108/13522751211215877 
26. Muzejsko dokumentacijski centar (2019). Muzeji, zbirke i riznice u vlasništvu vjerskih zajednica. http://www.mdc.hr/hr/mdc/zbirke-fondovi/registri/

27. Ozretić Došen, Đ. (2010). Osnove marketinga usluga. Zagreb: Mikrorad.

28. Pavičić, J. (2001). Ishodišne determinante strateškoga pristupa marketingu neprofitnih organizacija: teorijska razrada. Ekonomski pregled, (52)1-2,101124.

29. Pavičić, J., Alfirević, N. i Aleksić, Lj. (2006). Marketing i menadžment u kulturi i umjetnosti. Zagreb: Masmedia.

30. Pine, B. J. i Gilmore, J. H. (1998). Welcome to the Experience Economy. Harvard Business Review, July-August, 97-109.

31. Rentschler, R. (2004). Museum marketing: understanding different types of audiences. U F.

32. Kerrigan, P. Fraser i M. Özbilgin, (Ur.), Arts Marketing (str.139-158). Oxford: Elsevier Butterworth-Heinemann.

33. Rentschier, R. i Gilmore, A. (2002). Museums: Discovering Services Marketing. International Journal of Arts Management, (5)1, 62-72.

34. Retschler, R., Hede, A., i White, T. (2007). Museum princing: challenges to theory development and practice. International Journal of Nonprofit and Volunatary Sector Marketing, 12, 163-173. DOI: 10.1002/nvsm.289

35. Timothy, D. J. i Boyd, S.W. (2006). Heritage tourism in the 21st century: Valued traditions and new perspectives. Journal of heritage tourism, (1)1, 1-16. DOI: 10.1080/17438730608668462 Zakon o muzejima. NN 61/18 (2018). Dostupno na: https:// www.zakon.hr/z/302/Zakon-o-muzejima.

36. Zakon o pravnom položaju vjerskih zajednica. Pročišćeni tekst zakona. NN 83/02, 73/13 (***). Dostupno na: https://www.zakon.hr/z/284/Zakon-opravnom-polo\%C5\%BEaju-vjerskih-zajednica.

\section{Internetske stranice:}

- $\quad$ http://hbk.hr/dokumenti-hbk/uredba-hbk-o-crkvenim-muzejima-i-muzejskim-zbirkama/ [8. srpnja 2019.]

- $\quad$ http://hvm4.s10.novenaweb.info/knjiznica-hijacint-boskovic-zagreb,171/hr/ crkvene-zbirke//) [8. srpnja 2019.]

- $\quad$ http://hvm4.s10.novenaweb.info/muzej-dominikanskog-samostana-sv-dominika,45/hr/crkvene-zbirke// [8. srpnja 2019.] 
- $\quad$ http://hvm4.s10.novenaweb.info/zbirka-samostana-otaca-dominikanaca,47/ $\mathrm{hr} /$ crkvene-zbirke// [8. srpnja 2019.]

- $\quad$ https://mymodernmet.com/history-of-museums/ [23. ožujka 2019.]

- $\quad$ http://www.dominikanci.hr/ [7. siječnja 2019.]

- $\quad$ http://www.dominikanci.hr/index.php/9-vijesti/vijesti1/596-knjinica-hijacintbokovi [7. siječnja 2019.]

- $\quad$ http://www.dsspm.hr/ [7. siječnja 2019.]

- $\quad$ http://www.mdc.hr/hr/mdc/zbirke-fondovi/registri/ [7. siječnja 2019.]

\section{MARKETING SERVICES OF DOMINICAN MUSEUMS IN THE REPUBLIC OF CROATIA}

Summary

Religious organizations and communities possess and take care of a unique cultural and artistic heritage in their museums or galleries. Despite the considerable scope and exceptional value of collections, availability, and presentation of material to the public are still modest. This paper is dedicated to the marketing of services of museums of Dominican monasteries as a particular form of non-profit religious organizations. The purpose is to investigate whether Dominican museums use, how, and to what extent, marketing in designing and delivering their services. Exploratory qualitative research was carried out. The results indicate the presence of a limited number of marketing activities carried out to present the museum's material to the interested users and the public. There is a need to intensify marketing approach, primarily in monitoring the trends in the needs and wants of the users of museum services of culture and art and in communication with interested users and public. To improve marketing activities, it is essential to educate and employ people who care about museum artifacts, not only in terms of heritage conservation but also in marketing them, to design the Dominican monastery museum service as a unique, informative and educational experience. The limitations of the research are related to the nature of qualitative research and the fact that they are based on specific data, while the credibility of the interpretation of data depends on the data accuracy and completeness. The contribution stems from the selection of the original research problem and the results obtained, which enrich the theory and scientific bibliography in the field of non-profit (religious), and marketing of services (in culture and art).

Keywords: museum services marketing, marketing of religious organizations and communities, museums of Dominican monasteries in the Republic of Croatia 